\title{
The Residual Copper and Zinc in Tropical Soil over 21 Years after Amendment with Heavy Metal Containing Waste, Lime, and Compost
}

\author{
Abdul Kadir Salam ${ }^{D},{ }^{1}$ Asri Foresta Pakpahan, ${ }^{1}$ Galih Susilowati, ${ }^{1}$ Niko Fernando, \\ Nanik Sriyani, ${ }^{2}$ Sarno Sarno, ${ }^{1}$ Hery Novpriansyah, ${ }^{1}$ Sri Yusnaini, ${ }^{1}$ \\ and Dermiyati Dermiyati ${ }^{1}$ \\ ${ }^{1}$ Department of Soil Science, Faculty of Agriculture, University of Lampung, Bandar Lampung, Indonesia \\ ${ }^{2}$ Department of Agronomy and Horticulture, Faculty of Agriculture, University of Lampung, Bandar Lampung, Indonesia \\ Correspondence should be addressed to Abdul Kadir Salam; abdul.kadir@fp.unila.ac.id
}

Received 10 May 2021; Revised 16 September 2021; Accepted 28 September 2021; Published 31 October 2021

Academic Editor: Maman Turjaman

Copyright (c) 2021 Abdul Kadir Salam et al. This is an open access article distributed under the Creative Commons Attribution License, which permits unrestricted use, distribution, and reproduction in any medium, provided the original work is properly cited.

\begin{abstract}
This research aimed to evaluate the residual $\mathrm{Cu}$ and $\mathrm{Zn}$ in tropical soil over 21 years after amendment with industrial waste, lime, and compost. Soil samples were collected from a well-maintained experimental field amended one time with industrial waste high in $\mathrm{Cu}$ and $\mathrm{Zn}$ set in 1998 at about 1.5-20 years after amendment. Treatments were arranged in a randomized block design with a metal-wares industrial waste at rates 0,15 , and $60 \mathrm{Mg}^{-h^{-1}}$, lime at 0 and $5 \mathrm{Mg} \cdot \mathrm{ha}^{-1}$, and compost at 0 and $5 \mathrm{Mg} \cdot \mathrm{ha}^{-1}$. Soil samples were also taken vertically in the exact plot centers at depths of $0-75 \mathrm{~cm}$ of plots not amended with lime and compost and also from topsoils $(0-15 \mathrm{~cm})$ at 90 points with distances $50 \mathrm{~cm}$ between each other in each of the respective plots 21 years after amendment. Significant increases in $\mathrm{Cu}$ and $\mathrm{Zn}$ caused by waste were observed over 21 years. The increase in soil pH by lime was observed over 10 years but its effect in decreasing $\mathrm{Cu}$ and $\mathrm{Zn}$ was observed only at 1.5 years, particularly in topsoils. However, the effect of lime in lowering $\mathrm{Cu}$ and $\mathrm{Zn}$ was observed over 20 years when waste and/or compost were also given. Similarly, the effect of compost was absent over 20 years but significant when waste and/or lime were also given. The relative concentration of $\mathrm{Cu}$ and $\mathrm{Zn}$ in the $60 \mathrm{Mg}$ waste $\mathrm{ha}^{-1}$ plots decreased over 20 years to $17-53 \%$ for $\mathrm{Cu}$ and to $12-33 \%$ for $\mathrm{Zn}$; their concentrations were, in general, lower with lime and/or compost addition. The relative concentrations of $\mathrm{Cu}$ and $\mathrm{Zn}$ significantly decreased over 21 years in plots with 15 or $60 \mathrm{Mg} \cdot \mathrm{ha}^{-1}$ and increased in the control plots. Heavy metals moved in soil significantly through soil tillage and erosion and partially by leaching.
\end{abstract}

\section{Introduction}

High concentrations of heavy metals in soils must be properly managed [1-11]. Several chemical mechanisms have been intensively investigated to immobilize heavy metals in soils involving adsorption and precipitation [12-19]. These mechanisms have been reported to lower the heavy metal labile fractions in the soils [20-22]. Previous researches showed that the increase in soil $\mathrm{pH}$ by liming and in soil colloid negative charges by organic matter amendment significantly reduced the DTPA-extracted $\mathrm{Cu}, \mathrm{Cd}$, and
$\mathrm{Zn}$ in some tropical soils including Ultisols, Oxisols, and Alfisols. The negative effects of industrial waste-borne $\mathrm{Cu}$ and $\mathrm{Zn}$ on the growth of spinach (Amaranthus spinosus L.) and corn (Zea mays L.) were attenuated by lime and/or cassava-leaf compost amendment [23]. Some other soil workers also reported the reducing effects of lime and/or organic matters on soil heavy metal concentrations [22, 24-27].

However, heavy metals in soils are temporarily retained. Some soil workers $[28,29]$ showed the movement of some heavy metals in soils treated with heavy metal containing 
industrial waste years before the soil sampling. A particular amount of heavy metals may stay in the soil system due to their immobilization through chemical reactions like precipitation at high soil $\mathrm{pH}$ and adsorption at low soil $\mathrm{pH}$, particularly in soils with high cation exchange capacity (CEC) $[12,15,22,23]$. Parts of these heavy metals may with time release into the soil solution through desorption and dissolution processes $[15,30,31]$. Absorption of heavy metals by plant roots may speed up the release of the retained heavy metals on soil colloids [32-34]. Some physical processes like mass flow, diffusion, and leaching of heavy metals, as well as water runoff, erosion, and plowing/ tillage, may also accelerate the release and movement of the temporary adsorbed heavy metals $[29,35-40]$. The study in [41] reported that heavy metals moved vertically to deeper layers by soil tillage. The study in [42] also demonstrated that the waste-borne $\mathrm{Cu}$ and $\mathrm{Zn}$ moved to subsoil layers, probably by water leaching. To some extent, plowing and tillage may cause the most significant movement of heavy metals in the soil system. The study in [41] reported that soil tillage moved heavy metals to deeper layers of soils. Previously, the study in [35] reported that plowing may have moved heavy metals including $\mathrm{Cd}, \mathrm{Cu}$, and $\mathrm{Zn}$ in sludge amended soil out of the experimental plot boundaries. The destruction of soil matrix through mineral weathering and organic matter decomposition may also decrease the soil's ability to immobilize heavy metals [30, 43, 44]. All these processes may with time release the immobilized heavy metals into soil solution and cause dangers on the living things $[2,7,45-47]$.

Many research reports addressing the concentrations of heavy metals in soils years after heavy metal amendment are available in the literature $[28,30,35,37,48,49]$. The study in [48] reported the increase in soil heavy metals upon yearly treatment of municipal waste compost at rates $0-80 \mathrm{Mg} \cdot \mathrm{ha}^{-1}$. The study in [35] reported the redistribution of sludge-borne heavy metals in the experimental plots years after treatment. The data on the spatial distribution of heavy metals in tropical soils, particularly those in soils treated with high amounts of heavy metals, are not available. The objective of this research was to study the residual spatial and vertical distribution of $\mathrm{Cu}$ and $\mathrm{Zn}$ in the experimental plots treated with a $\mathrm{Cu}$ and $\mathrm{Zn}$ containing waste over 21 years after amendment. Tropical soils are unique and different from those of temperate soils due to their high contents of secondary minerals with low CEC affected by high water precipitation that may cause high water leaching and heavy metal movement.

\section{Materials and Methods}

2.1. Soil Samples, Experimental Field, and Experimental Design. Soil samples were collected from a well-maintained experimental field amended one time with an industrial waste high in $\mathrm{Cu}$ and $\mathrm{Zn}$ set in 1998 located in Sidosari, Natar, South Lampung, Indonesia, reported previously (Figure 1) [23, 50]. The experimental field measured $30.5 \mathrm{~m} \times 26.5 \mathrm{~m}$ and was a part of an active upland agricultural land with a slope of 2.5-3.0\%
(Figure 2). The soil in the experimental field was an Ultisol characterized by textural properties $41.2 \%$ sand, $26.0 \%$ silt, and $32.8 \%$ clay (Textural Class of Sandy Clay Loam); $\mathrm{pH}$ of 5.11, organic C content of $1.28 \mathrm{~g} \cdot \mathrm{kg}^{-1}$, and $\mathrm{Cu}$ and $\mathrm{Zn}$ of 1.28 and $1.60 \mathrm{mg} \cdot \mathrm{kg}^{-1}$, respectively [23], listed in Table 1 . The average rainfall in South Lampung was fairly high. The total rainfall in 2015 was $1.628 \mathrm{~mm}$ with 143 rainy days [51].

Treatments in the experimental field were arranged in a randomized block design and consisted of 3 factors: industrial waste, lime, and cassava-leaf compost, replicated 3 times. Industrial waste was a metal-wares industrial waste taken from CV Star Metal Wares Jakarta characterized by high $\mathrm{Cu}$ and $\mathrm{Zn}$ (Table 1). Some properties of the industrial waste were $\mathrm{Cu} \quad 754 \mathrm{mg} \cdot \mathrm{kg}^{-1}, \mathrm{Zn} \quad 44.6 \mathrm{mg} \cdot \mathrm{kg}^{-1}, \quad \mathrm{~Pb}$ $2.44 \mathrm{mg} \cdot \mathrm{kg}^{-1}, \mathrm{Cd} 0.12 \mathrm{mg} \cdot \mathrm{kg}^{-1}$, and $\mathrm{pH} 7.30$ [42]. The waste was air-dried and ground to pass a $1 \mathrm{~mm}$ sieve and given one time at 3 levels: 0,15 , and $60 \mathrm{Mg} \cdot \mathrm{ha}^{-1}$. Lime was $\mathrm{CaCO}_{3}$

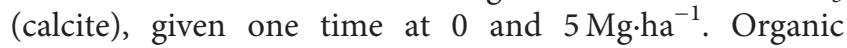
compost was made of cassava (Manihot utilissima) leaf prepared as reported previously [23], also given one time at 0 and $5 \mathrm{Mg} \mathrm{ha}^{-1}$. Rates of industrial waste, lime, and cassavaleaf compost were selected through several preliminary laboratory and glasshouse experiments conducted in 1995-1998 reported previously [23]. The rates of industrial waste were determined to set the heavy metal level into 3 categories: control, low heavy metal, and high heavy metal, particularly for $\mathrm{Cu}$, which was found the highest in the waste (Table 1). The soil extracted $\mathrm{Cu}$ of more than $100 \mathrm{mg} \cdot \mathrm{kg}^{-1}$ was considered high [48]. Lime at $5 \mathrm{Mg} \mathrm{CaCO} \cdot \mathrm{ha}^{-1}$ was to increase the soil $\mathrm{pH} 1$ unit higher than the initial value. The field arrangement of the experimental plots in the field is depicted in Figure 2

Each plot measured $450 \mathrm{~cm}$ long and $400 \mathrm{~cm}$ wide, with distances $50 \mathrm{~cm}$ between plots and $100 \mathrm{~cm}$ between blocks. The total number of the experimental plots was 36 separated into 3 blocks. Borders were imaginary, permanently marked only in several points, to ease plowing, planting, and plant maintenance, and therefore, it was possible for the soil masses to move between plots and blocks during plowing and harrowing. The industrial waste was broadcasted on the surface of the soil and mixed thoroughly by plowing $(0-15 \mathrm{~cm})$. Lime and cassava-leaf compost were both given into $0-15 \mathrm{~cm}$ depth by plowing one week after waste treatment. The experimental plots were planted with various crops since 1998, first planted with corn, and then dryland paddy, cassava, peanut, and sometimes left bare in between. Plowing and harrowing before planting were conducted twice, each in the direction N-S and E-W vice versa.

To evaluate the residual $\mathrm{Cu}$ and $\mathrm{Zn}$ in soils, three evaluations were conducted. The first evaluation was to study the residual $\mathrm{Cu}$ and $\mathrm{Zn}$ in topsoil $(0-15 \mathrm{~cm})$ and subsoil $(15-30 \mathrm{~cm})$ in all experimental plots over a time span of 20 years. The second evaluation was to study the vertical spatial distribution of $\mathrm{Cu}$ and $\mathrm{Zn}$ over time in the experimental plots treated only with industrial waste at 0,15 , and $60 \mathrm{Mg} \cdot \mathrm{ha}^{-1}$. The third evaluation was to study the horizontal spatial distribution of $\mathrm{Cu}$ and $\mathrm{Zn}$ in the experimental plots treated only with industrial waste at 0,15 , and $60 \mathrm{Mg} \cdot \mathrm{ha}^{-1}$. 


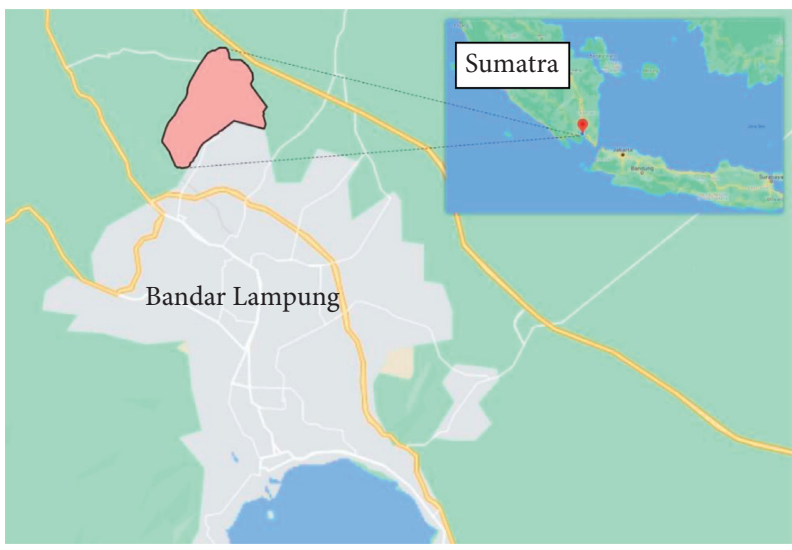

FIGURE 1: Geographical location of the experimental plots.

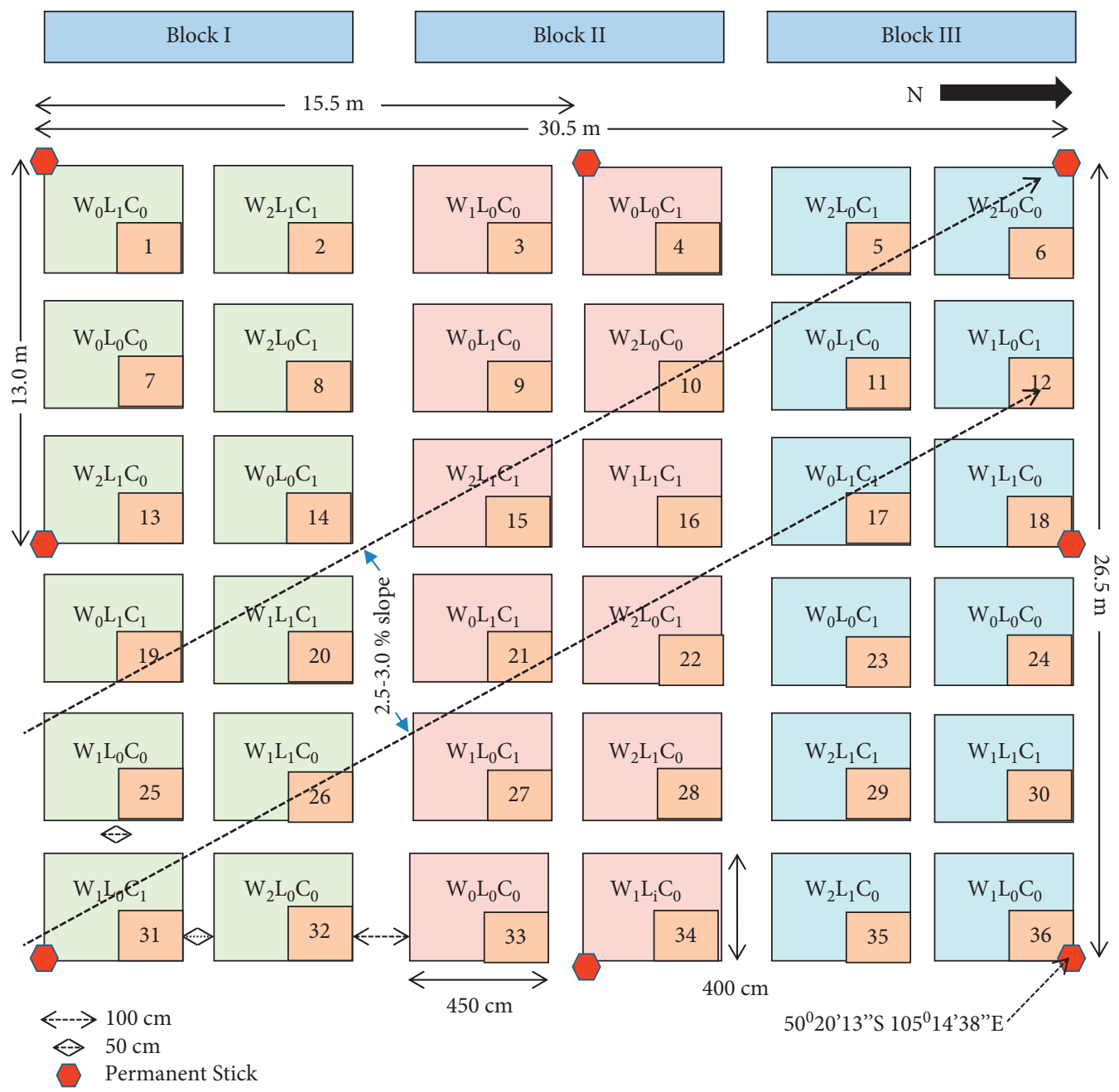

Figure 2: The arrangement of the experimental plots set in 1998 ( $W=$ industrial waste, $W_{0}=0, W_{1}=15, W_{2}=60 \mathrm{Mg} \cdot \mathrm{ha}{ }^{-1} ; L=$ lime, $L_{0}=0$, $L_{1}=5 \mathrm{Mg}$ calcite $\cdot \mathrm{ha}^{-1} ; C=$ cassava-leaf compost, $\left.C_{0}=0, C_{1}=5 \mathrm{Mg} \cdot \mathrm{ha}^{-1}\right)$.

2.2. Evaluation of the Residual $\mathrm{Cu}$ and $\mathrm{Zn}$ over 20 Years. To reach the purpose of this research, soil samples were collected and analyzed for $\mathrm{Cu}$ and $\mathrm{Zn}$ from all experimental units (plot nos. 1-36 in Figure 2) at particular times over the last 20 years (1998-2018). The latest soil sampling was conducted on July 20, 2018 (almost 20 years after the amendment). Composite topsoil $(0-15 \mathrm{~cm})$ and subsoil $(15-30 \mathrm{~cm})$ samples were taken diagonally from 5 points in each plot. For the purpose of this research, this data was compared to those of \pm 1.5 years, \pm 3 years [ 42 ], and \pm 10 years 
TABLE 1: Selected initial properties of materials used in the experiment.

\begin{tabular}{|c|c|c|c|c|}
\hline \multirow{2}{*}{ Properties } & \multirow{2}{*}{ Methods } & \multicolumn{3}{|c|}{ Materials } \\
\hline & & Soil & Compost & Industrial waste \\
\hline Sand (\%) & Hydrometer & 41.2 & & \\
\hline Silt (\%) & Hydrometer & 26.0 & & \\
\hline Clay (\%) & Hydrometer & 32.8 & & \\
\hline $\mathrm{pHH}_{2} \mathrm{O}(1: 2)$ & Electrode & 5.11 & & 7.3 \\
\hline Organic $\mathrm{C}\left(\mathrm{g} \mathrm{kg}^{-1}\right)$ & Walkey and black & 1.28 & 275 & \\
\hline Total N $\left(\mathrm{g} \mathrm{kg}^{-1}\right)$ & Kjeldahl & & 40.1 & \\
\hline $\mathrm{C} / \mathrm{N}$ & & & 6.85 & \\
\hline $\mathrm{Cu}\left(\mathrm{mg} \mathrm{kg}^{-1}\right)$ & DTPA & 1.60 & & 754 \\
\hline $\mathrm{Zn}\left(\mathrm{mg} \mathrm{kg}^{-1}\right)$ & DTPA & 0.89 & & 44.6 \\
\hline $\mathrm{Pb}\left(\mathrm{mg} \mathrm{kg}^{-1}\right)$ & DTPA & 0.08 & & 2.44 \\
\hline $\mathrm{Cd}\left(\mathrm{mg} \mathrm{kg}^{-1}\right)$ & DTPA & nd & & 0.12 \\
\hline
\end{tabular}

nd stands for below detection limit; after [50].

after amendment [50]. The method of soil sampling and analysis for this research was the same as that conducted for \pm 10 years after amendment.

\subsection{Evaluation of the Vertical Spatial Distribution of $\mathrm{Cu}$ and} $\mathrm{Zn}$ in the Experimental Plots. Depth-wise soil samples were also collected from the exact centers of the experimental plots to investigate the vertical distribution of $\mathrm{Cu}$ and $\mathrm{Zn}$ (Table 2). The soil samples were taken depth-wisely using a Belgian auger at $0-15,15-30,30-45,45-60$, and $60-75 \mathrm{~cm}$ (Figure 3), conducted in January 2019 ( \pm 21 years after amendment) from 9 plots comprising 3 plots with no addition of industrial waste with no lime and no organic compost (control plot (CP)) including plot nos. 7, 24, and 33, 3 plots with $15 \mathrm{Mg}$ waste $\mathrm{ha}^{-1}$, no lime, and no organic compost treatment (low metal plot (LMP)) including plot nos. 3,25 , and 36 , and 3 plots with $60 \mathrm{Mg}$ waste ha ${ }^{-1}$, no lime, and no organic compost treatment (high metal plot (HMP)) including plot nos. 6, 10, and 32 in Figure 2. The total experimental units sampled were 9 plots comprising 3 levels of industrial waste treatment levels with 3 replications.

2.4. Evaluation of the Horizontal Spatial Distribution of $\mathrm{Cu}$ and $\mathrm{Zn}$ in the Experimental Plots. Soil samples were also purposively collected in January $2019( \pm 21$ years after amendment) from the $A_{p}$ horizons $(0-15 \mathrm{~cm})$ of the experimental plots to evaluate the horizontal spatial distribution of $\mathrm{Cu}$ and $\mathrm{Zn}$. The soil samples were collected only from 3 plots representing CP (plot no. 7), LMP (plot no. 36), and HMP (plot no. 10 in Figure 2). The soil samples were collected using an auger from 90 sites in each plot located $50 \mathrm{~cm}$ apart between sites (Figure 4).

2.5. Soil and Data Analysis. Each soil sample was air-dried, ground to pass a $2 \mathrm{~mm}$ sieve, thoroughly mixed, and then analyzed for the soil $\mathrm{pH}$, organic $\mathrm{C}$, and the concentrations of $\mathrm{Cu}$ and $\mathrm{Zn}$. The soil $\mathrm{pH}(1: 2)$ was determined with a $\mathrm{pH}$ electrode, organic $\mathrm{C}$ with the method of Walkley and Black, and heavy metal analysis with the DTPA method [52]. The extracting solution was prepared following the procedure in the method. Exactly $1.96 \mathrm{~g}$ diethylene triamine pentaacetic acid powder and $14.92 \mathrm{~g}$ triethanolamine were dissolved in about $900 \mathrm{ml}$ distilled water in a $1000 \mathrm{ml}$ beaker glass. After added with $1.47 \mathrm{~g} \mathrm{CaCl}_{2} \cdot 2 \mathrm{H}_{2} \mathrm{O}$ and the $\mathrm{pH}$ adjusted to 7.30 , the solution was quantitatively moved into a $1000 \mathrm{ml}$ volumetric flask and the volume was adjusted to $1000 \mathrm{ml}$ with deionized water, after which the solution was thoroughly mixed.

The heavy metal analysis was conducted by extracting $10 \mathrm{~g}$ oven-dry equivalent $\left(105{ }^{0} \mathrm{C} 24\right.$ hours $)$ of air-dry soil sample with $20 \mathrm{ml}$ of the DTPA extracting solution in an end-to-end shaker for 2 hours. The filtrate of the extract (using Whatman Paper No. 42) was determined for $\mathrm{Cu}$ and Zn using the iCE 3000 flame atomic absorption spectrophotometer (flame AAS) at $\lambda=324.7 \mathrm{~nm}$ for $\mathrm{Cu}$ and $\lambda=213.9 \mathrm{~nm}$ for $\mathrm{Zn}$.

The data for evaluation 1 was evaluated using variance analysis (ANOVA) at 1 and 5\% significant levels. The changes in the concentration of $\mathrm{Cu}$ and $\mathrm{Zn}$ over time were presented as the relative concentrations $\left(R_{M}\right)$, calculated by

$$
R_{M}=100 \times \frac{M}{M_{0}-1.5}
$$

where $R_{\mathrm{M}}$ was the relative concentration of heavy metal $M$ (expressed in \%), $M$ is the concentration of heavy metal $M$, and $\mathrm{M}_{0}-1.5$ was the concentration of heavy metal $M$ in the control plot (no compost and no lime) observed at 1.5 years which equaled to $122 \mathrm{mg} \cdot \mathrm{kg}^{-1}$ for $\mathrm{Cu}$ and $116.6 \mathrm{mg} \mathrm{kg}^{-1}$ for $\mathrm{Zn}$ at the waste level of $60 \mathrm{Mg} \cdot \mathrm{ha}^{-1}$, which were considered the highest. This data was needed to evaluate the trend of heavy metal immobilization over 20 years as affected by lime and/or compost.

The changes in the concentration of $\mathrm{Cu}$ and $\mathrm{Zn}$ over soil depth were also presented as $R_{\mathrm{M}}$, calculated by

$$
R_{M}=100 \times \frac{M}{M_{0}},
$$

where $R_{\mathrm{M}}$ was the relative concentration of heavy metal $M$ (expressed in \%), $M$ is the concentration of heavy metal $M$ at a particular soil depth, and $M_{0}$ was the highest concentration of $M$ in the $60 \mathrm{Mg}$ waste ha ${ }^{-1}$ plot. 
TABLe 2: The soil samples used in the evaluation of the $\mathrm{Cu}$ and $\mathrm{Zn}$ vertical and spatial distribution.

\begin{tabular}{|c|c|c|c|}
\hline Soil plot & Industrial waste (W) & $\begin{array}{c}\text { Lime (L) } \\
\text { Mg.ha }^{-1}\end{array}$ & Organic compost (C) \\
\hline Control, CP & 0 & 0 & 0 \\
\hline Low metal, LMP & 15 & 0 & 0 \\
\hline High metal, HMP & 60 & 0 & 0 \\
\hline
\end{tabular}

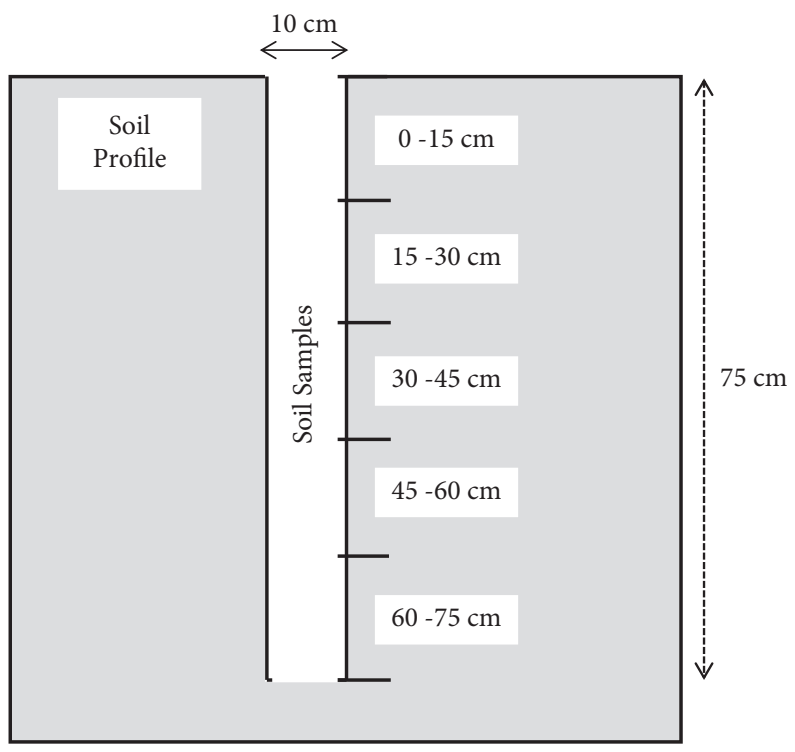

Figure 3: Depth-wise soil sampling with $15 \mathrm{~cm}$ intervals.

\section{Results}

3.1. Changes in the Residual $\mathrm{Cu}$ and $\mathrm{Zn}$ over 20 Years after Waste Amendment. The soil concentrations of $\mathrm{Cu}$ and $\mathrm{Zn}$ were in general enhanced by the addition of the industrial waste, as were also reported previously $[42,50]$. Analysis of variance (ANOVA) shows the significant increases in the soil concentrations of $\mathrm{Cu}$ and $\mathrm{Zn}$ by waste amendment over 20 years after amendment in 1998 with the exception for $\mathrm{Zn}$ at 20 years (Tables 3 and 4 ).

Even though organic compost was reported to increase the soil adsorption capacity toward heavy metals, particularly right after treatment [23], it did not affect the retainment of $\mathrm{Cu}$ and $\mathrm{Zn}$ after a long time (Tables 3 and 4). However, when combined with waste or lime treatment, organic compost significantly decreased the soil concentrations of $\mathrm{Cu}$ and $\mathrm{Zn}$ (Tables 3 and 4 ) at 3 and 10 years after treatment. However, lime treatment increased the soil $\mathrm{pH}$ until 10 years while waste only until 3 years after amendment particularly in topsoils (Table 5). The significant effect of organic compost on soil concentrations of $\mathrm{Cu}$ and $\mathrm{Zn}$ was also observed at 3, 10, and 20 years when compost was combined with waste and lime (Tables 3 and 4).

The relative concentrations of $\mathrm{Cu}$ and $\mathrm{Zn}\left(\mathrm{R}_{\mathrm{Cu}}\right.$ and $\left.\mathrm{R}_{\mathrm{Zn}}\right)$ as affected by lime and/or cassava-leaf compost and time of sampling in plots with the highest waste addition of $60 \mathrm{Mg} \cdot \mathrm{ha}^{-1}$ (HMP) are shown in Figures 5 and 6, respectively. These data clearly show that in general the $\mathrm{R}_{\mathrm{Cu}}$ and $\mathrm{R}_{\mathrm{Zn}}$ decreased with time of sampling over 20 years. These values indicate that the concentrations of $\mathrm{Cu}$ and $\mathrm{Zn}$ decreased with time. The expected effect of compost and/or lime, where compost and/or lime lowered the concentrations of $\mathrm{Cu}$ and $\mathrm{Zn}$, was observed. In general, with some exception on the particular time of sampling, the $R_{C u}$ (Figure 5) and the $\mathrm{R}_{\mathrm{Zn}}$ (Figure 6) follow the order of (control or no compost + no lime $)>(\mathrm{C}$ or with compost + no lime $)$ $>(\mathrm{L}$ or no compost + with lime $)>(C+L$ or with compost + with lime). This trend is more obvious until 3 years for $\mathrm{Cu}$ and until 10 years after the amendment for $\mathrm{Zn} . \mathrm{R}_{\mathrm{Cu}}$ and $\mathrm{R}_{\mathrm{Zn}}$ decreased over 20 years to $17-53 \%$ for $\mathrm{Cu}$ and to $12-33 \%$ for $\mathrm{Zn}$; their concentrations were in general lower with lime and/or compost.

\subsection{Vertical Spatial Distribution of the Residual Cu and Zn 21} Years after Waste Amendment. The vertical spatial distribution of the residual $\mathrm{Cu}$ and $\mathrm{Zn}$ is depicted in Figures 7 and 8 , respectively. The concentrations of $\mathrm{Cu}$ and $\mathrm{Zn}$ followed the order of high metal plot (HMP) > low metal plot (LMP) $>$ control plot (CP). The concentrations of $\mathrm{Cu}$ and $\mathrm{Zn}$ were the highest in the $0-15 \mathrm{~cm}$ layers of LMP and HMP plots where waste was amended one time in 1998 and then in the $15-30 \mathrm{~cm}$ layers. Some significant amounts of $\mathrm{Cu}$ and $\mathrm{Zn}$ were observed in 30-60 cm layers, particularly in HMP, and insignificant amounts in CP and LMP.

The concentrations of $\mathrm{Zn}$ were lower at 20 years than those at 3 years (Figure 8). The concentrations of $\mathrm{Cu}$ were also lower at 20 years than those at 3 years in HMP but 


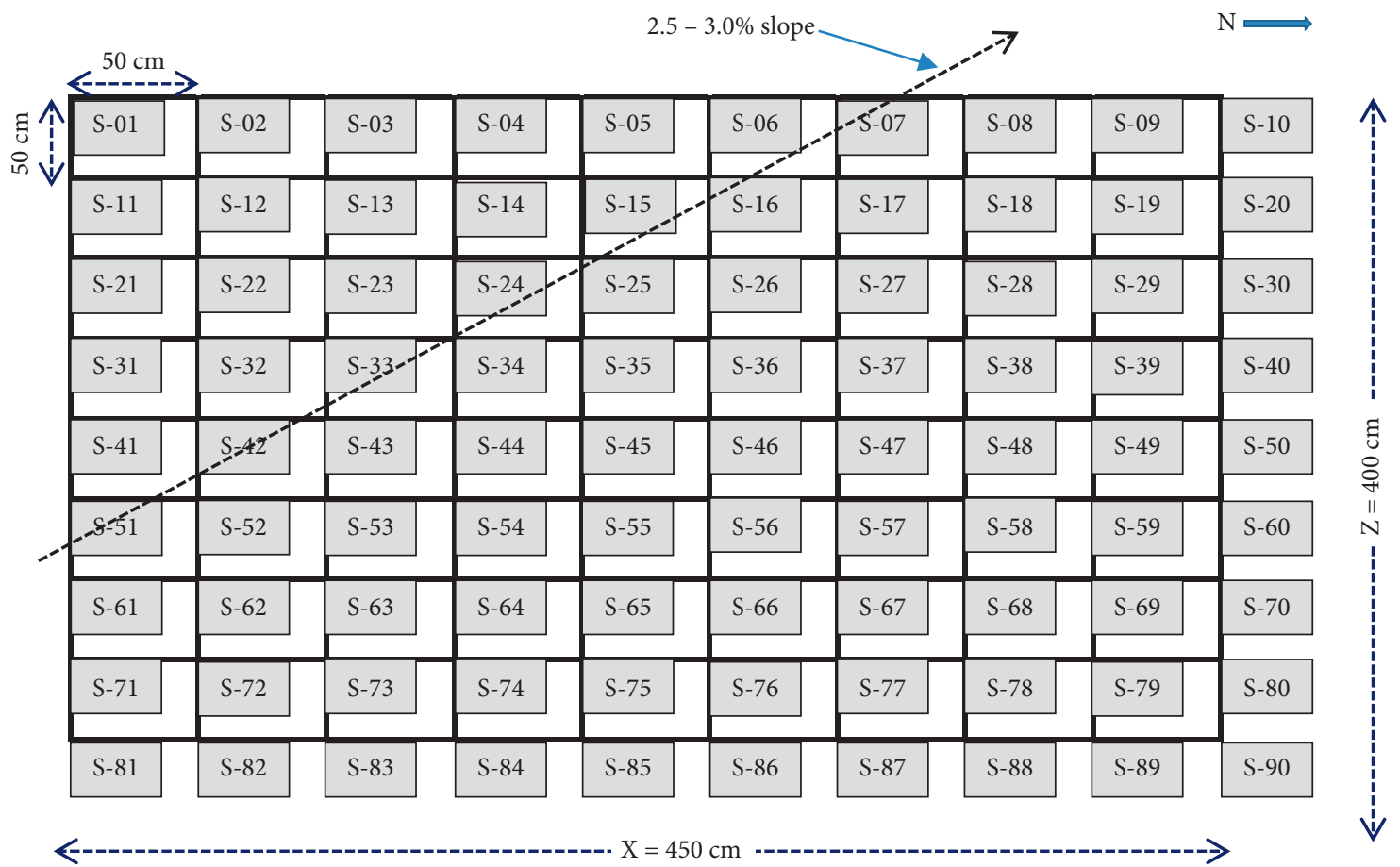

FIgURE 4: The sampling sites of soil in each experimental plot (the experimental plot measured $450 \mathrm{~cm}(\mathbf{X}) \times 400 \mathrm{~cm}(\mathbf{Z})$; the number of soil samples $=90$ per plot, i.e., S-01 through S-90).

Table 3: The effect of the 20-year-old amendment of industrial waste, lime, and cassava-leaf compost on the soil Cu concentration.

\begin{tabular}{|c|c|c|c|c|c|c|c|c|}
\hline \multirow{3}{*}{ Treatment } & \multicolumn{8}{|c|}{ Time (years) } \\
\hline & \multicolumn{2}{|c|}{ $\pm 1.5^{1)}$} & \multicolumn{2}{|c|}{ $\pm 3^{1)}$} & \multicolumn{2}{|c|}{ $\pm 10^{1)}$} & \multicolumn{2}{|c|}{ $\pm 20^{2)}$} \\
\hline & $0-15 \mathrm{~cm}$ & $15-30 \mathrm{~cm}$ & $0-15 \mathrm{~cm}$ & $15-30 \mathrm{~cm}$ & $0-15 \mathrm{~cm}$ & $15-30 \mathrm{~cm}$ & $0-15 \mathrm{~cm}$ & $15-30 \mathrm{~cm}$ \\
\hline $\mathrm{W}$ & ** & $* *$ & $* *$ & $* *$ & $* *$ & $* *$ & * & ns \\
\hline $\mathrm{C}$ & ns & ns & ns & $* *$ & ns & ns & ns & ns \\
\hline $\mathrm{L}$ & $* *$ & ns & ns & ns & ns & ns & ns & ns \\
\hline $\mathrm{WxC}$ & ns & ns & ns & $* *$ & $* *$ & $* *$ & $* *$ & ns \\
\hline WxL & ns & ns & $* *$ & ns & $* *$ & $* *$ & $* *$ & ns \\
\hline $\mathrm{CxL}$ & ns & ns & ns & $* *$ & ns & ns & $*$ & $\mathrm{~ns}$ \\
\hline WxCxL & ns & ns & $* *$ & $* *$ & ns & $* *$ & $* *$ & ns \\
\hline
\end{tabular}

Note: $W=$ waste, $C=$ cassava-leaf compost, and $L=$ lime; ${ }^{*}=$ significant at $5 \%,{ }^{* *}=$ significant at $1 \%$, and ns $=$ not significant at $5 \%$ and $1 \%$ ANOVA; ${ }^{1}$ after [50] and ${ }^{2)}$ after Susilowati and Salam (unpublished data 2018).

TABle 4: The effect of the 20-year-old amendment of industrial waste, lime, and cassava-leaf compost on the soil Zn concentration.

\begin{tabular}{|c|c|c|c|c|c|c|c|c|}
\hline \multirow{3}{*}{ Treatment } & \multicolumn{8}{|c|}{ Time (years) } \\
\hline & \multicolumn{2}{|c|}{ $\pm 1.5^{1)}$} & \multicolumn{2}{|c|}{ $\pm 3^{2)}$} & \multicolumn{2}{|c|}{ $\pm 10^{3)}$} & \multicolumn{2}{|c|}{ $\pm 20^{4)}$} \\
\hline & $0-15 \mathrm{~cm}$ & $15-30 \mathrm{~cm}$ & $0-15 \mathrm{~cm}$ & $15-30 \mathrm{~cm}$ & $0-15 \mathrm{~cm}$ & $15-30 \mathrm{~cm}$ & $0-15 \mathrm{~cm}$ & $15-30 \mathrm{~cm}$ \\
\hline $\mathrm{W}$ & $* *$ & $* *$ & $* *$ & $* *$ & $* *$ & $* *$ & ns & ns \\
\hline C & ns & ns & ns & ns & ns & ns & ns & ns \\
\hline $\mathrm{L}$ & $* *$ & $*$ & ns & ns & ns & ns & ns & ns \\
\hline $\mathrm{WxC}$ & ns & ns & $*$ & ns & $* *$ & $* *$ & $*$ & ns \\
\hline WxL & ns & $* *$ & $*$ & ns & $* *$ & $* *$ & $* *$ & $*$ \\
\hline $\mathrm{CxL}$ & ns & ns & $* *$ & ns & $*$ & $*$ & $*$ & $*$ \\
\hline WxCxL & ns & ns & $* *$ & ns & $*$ & $* *$ & $*$ & $*$ \\
\hline
\end{tabular}

Note: $W=$ waste, $C=$ cassava-leaf compost, and $L=$ lime; ${ }^{*}=$ significant at $5 \%,{ }^{* *}=$ significant at $1 \%$, and ns $=$ not significant at $5 \%$ and $1 \%$ ANOVA; ${ }^{1)}$ after Amirulloh and Salam (unpublished data 2000), ${ }^{2}$ after [42], ${ }^{3)}$ after [50], and ${ }^{4)}$ after Susilowati and Salam (unpublished data 2018). 
TABle 5: The effect of the 20-year-old amendment of industrial waste, lime, and cassava-leaf compost on the soil pH.

\begin{tabular}{|c|c|c|c|c|c|c|c|c|}
\hline \multirow{3}{*}{ Treatment } & \multicolumn{8}{|c|}{ Time (years) } \\
\hline & \multicolumn{2}{|c|}{ $\pm 1.5^{1)}$} & \multicolumn{2}{|c|}{ $\pm 3^{2)}$} & \multicolumn{2}{|c|}{ $\pm 10^{3)}$} & \multicolumn{2}{|c|}{ $\pm 20^{4)}$} \\
\hline & $0-15 \mathrm{~cm}$ & $15-30 \mathrm{~cm}$ & $0-15 \mathrm{~cm}$ & $15-30 \mathrm{~cm}$ & $0-15 \mathrm{~cm}$ & $15-30 \mathrm{~cm}$ & $0-15 \mathrm{~cm}$ & $15-30 \mathrm{~cm}$ \\
\hline $\mathrm{W}$ & * & ns & $* *$ & ns & ns & ns & ns & ns \\
\hline $\mathrm{C}$ & ns & ns & ns & ns & $*$ & ns & ns & ns \\
\hline $\mathrm{L}$ & $* *$ & $* *$ & $* *$ & $* *$ & $* *$ & $* *$ & ns & ns \\
\hline $\mathrm{WxC}$ & ns & ns & ns & * & ns & ns & ns & ns \\
\hline $\mathrm{WxL}$ & $* *$ & ns & ns & ns & $* *$ & $* *$ & ns & ns \\
\hline $\mathrm{CxL}$ & ns & ns & $* *$ & ns & $* *$ & $* *$ & ns & ns \\
\hline $\mathrm{WxCxL}$ & ns & ns & ns & ns & ns & * & ns & $\mathrm{ns}$ \\
\hline
\end{tabular}

Note: $W=$ waste, $C=$ cassava-leaf compost, and $L=$ lime; ${ }^{*}=$ significant at $5 \%,{ }^{* *}=$ significant at $1 \%$, and ns $=$ not significant at $5 \%$ and $1 \%$ ANOVA; ${ }^{1)}$ after Amirulloh and Salam (unpublished data 2000), ${ }^{2)}$ after [42], ${ }^{3)}$ after [50], and ${ }^{4}$ after Susilowati and Salam (unpublished data 2018).

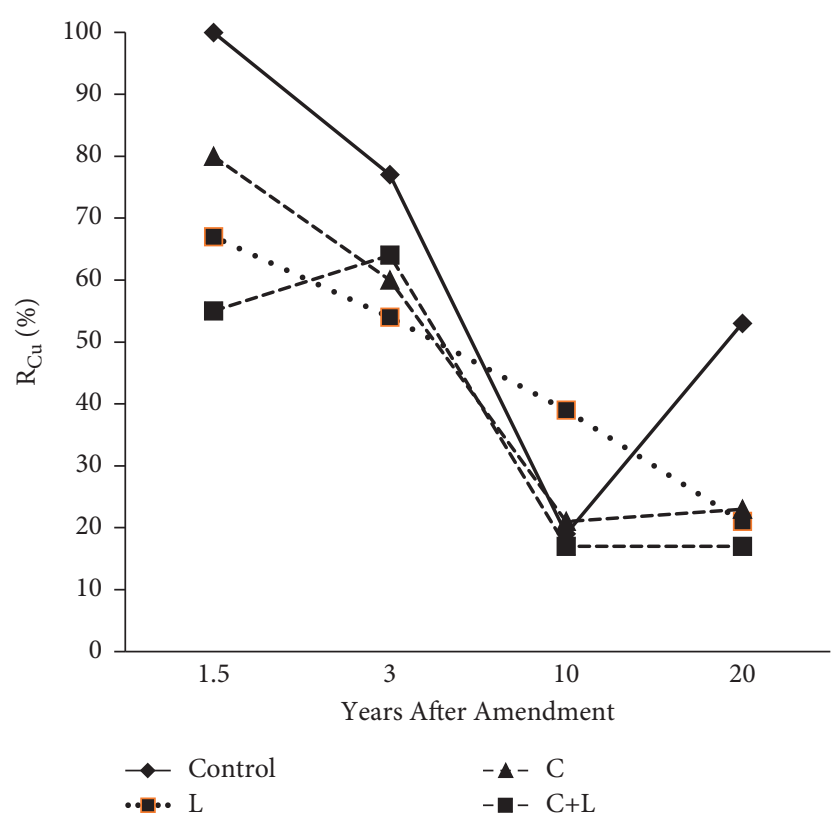

Figure 5: The relative concentrations of $\mathrm{Cu}\left(R_{\mathrm{Cu}}=100 \mathrm{x} \mathrm{Cu} / \mathrm{Cu}_{0}-1.5\right)$ in topsoil amended with $60 \mathrm{Mg}$ waste ha ${ }^{-1}$ (HMP) (after Amirulloh and Salam (unpublished data, 2000) for 1.5 years, after [42] for 3 years, after [50] for 10 years, and after Susilowati and Salam (unpublished data 2018) for 20 years; the concentration of $\mathrm{Cu}$ in the topsoil of control at 1.5 years $\left(\mathrm{Cu}_{0}-1.5\right)$ was $122 \mathrm{mg} \cdot \mathrm{kg}^{-1}$ (L: lime at $5 \mathrm{Mg} \cdot \mathrm{ha}{ }^{-1}$; C: cassava-leaf compost at $5 \mathrm{Mg} \cdot \mathrm{ha}^{-1}$ ).

higher in 20 years than those at 3 years in CP and LMP (Figure 7). Since the industrial waste was given only one time, this phenomenon indicates the decrease in soil heavy metal concentration with time.

\subsection{Horizontal Spatial Distribution of the Residual Cu and $\mathrm{Zn}$} 21 Years after Waste Amendment. The horizontal spatial distributions of $\mathrm{Cu}$ and $\mathrm{Zn}$ in the $0-15 \mathrm{~cm}$ layer of the soil in the experimental plots are depicted in Figures 9 and 10, respectively. The $\mathrm{Cu}$ and $\mathrm{Zn}$ in the topsoils were not evenly distributed. The concentration of $\mathrm{Cu}$ was on average below $10 \mathrm{mg} \cdot \mathrm{kg}^{-1}$ in the CP and LMP ranging from $<10$ to about $55 \mathrm{mg} \cdot \mathrm{kg}^{-1}$ in HMP (Figure 9). However, the $\mathrm{Cu}$ in topsoils treated with $60 \mathrm{Mg}$ waste $\mathrm{ha}^{-1}$ (HMP) was observed significantly high.
Similar phenomena were also observed in the concentration of $\mathrm{Zn}$ in the $0-15 \mathrm{~cm}$ of the soil. The concentrations of $\mathrm{Zn}$ in the plots were also not evenly distributed in topsoils. The average concentration of $\mathrm{Zn}$ was $<5 \mathrm{mg} \cdot \mathrm{kg}^{-1}$ in $\mathrm{CP}$, ranging from about 0 to $12 \mathrm{mg} \mathrm{kg}^{-1}$ in LMP and ranging from about 5 to $60 \mathrm{mg} \cdot \mathrm{kg}^{-1}$ in HMP (Figure 10). The concentrations of $\mathrm{Zn}$ in topsoils treated with $60 \mathrm{Mg}$ waste $\mathrm{ha}^{-1}$ (HMP) were also observed significantly high. The concentrations of $\mathrm{Cu}$ and $\mathrm{Zn}$ were also observed to be higher in the northwest parts of the plots, particularly in plots treated with $60 \mathrm{Mg}$ waste ha ${ }^{-1}$ (Figures 9 and 10).

The concentrations of $\mathrm{Cu}$ and $\mathrm{Zn}$ in waste amended plots (LMP and HMP) significantly decreased over the period of 1998-2019. On the other hand, those in the control (CP) increased. The changes in the concentrations of $\mathrm{Cu}$ and $\mathrm{Zn}$ over the last 21 years are listed in Table 6 . 


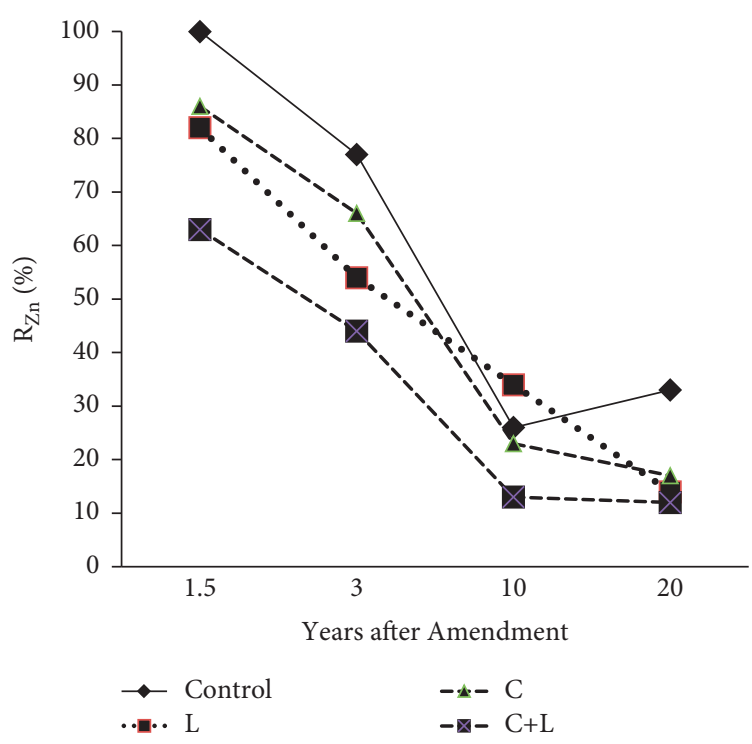

Figure 6: The relative concentrations of $\mathrm{Zn}\left(R_{\mathrm{Zn}}=100 \times \mathrm{Zn} / \mathrm{Zn}_{0}-1.5\right)$ in topsoil amended with $60 \mathrm{Mg}$ waste ha ${ }^{-1}$ (HMP) (after Amirulloh and Salam (unpublished data, 2000) for 1.5 years, after [42] for 3 years, after [50] for 10 years, and after Susilowati and Salam (unpublished data, 2018) for 20 years; the concentration of $\mathrm{Zn}$ in the topsoil of control at 1.5 years was $116.6 \mathrm{mg} \cdot \mathrm{kg}^{-1}\left(\mathrm{Zn}_{0}-1.5\right)\left(\mathrm{L}\right.$ : lime at $5 \mathrm{Mg} \cdot \mathrm{ha}{ }^{-1}$; C: cassava-leaf compost at $5 \mathrm{Mg} \cdot \mathrm{ha}^{-1}$ ).
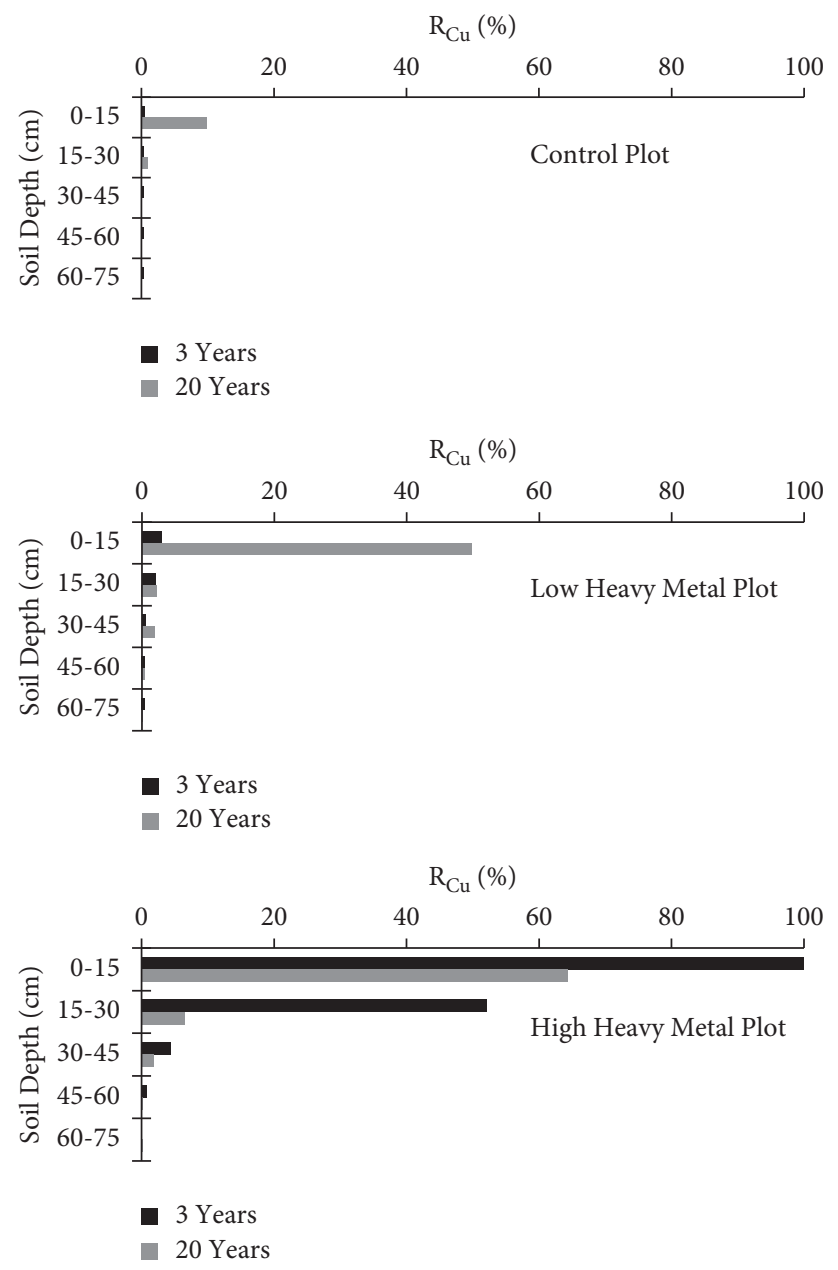

Figure 7: The vertical spatial distribution of soil $\mathrm{Cu} 3$ years $^{1)}$ and 20 years ${ }^{2)}$ after amendment with $\mathrm{Cu}-\mathrm{Zn}$ containing industrial waste $\left(\mathrm{R}_{\mathrm{Cu}}\right.$ is the ratio of the actual concentration to the highest concentration of $\mathrm{Cu}$ in the $60 \mathrm{Mg}$ waste ha ${ }^{-1}$ plot $\left(93.3 \mathrm{mg} \cdot \mathrm{kg}^{-1}\right)$; waste at $\mathrm{CP}=0$, $\mathrm{LMP}=15$, and $\mathrm{HMP}=60 \mathrm{Mg} \cdot \mathrm{ha}^{-1} ;{ }^{1)}$ after $[42]{ }^{2)}$ after Fernando and Salam (unpublished data 2018)). 

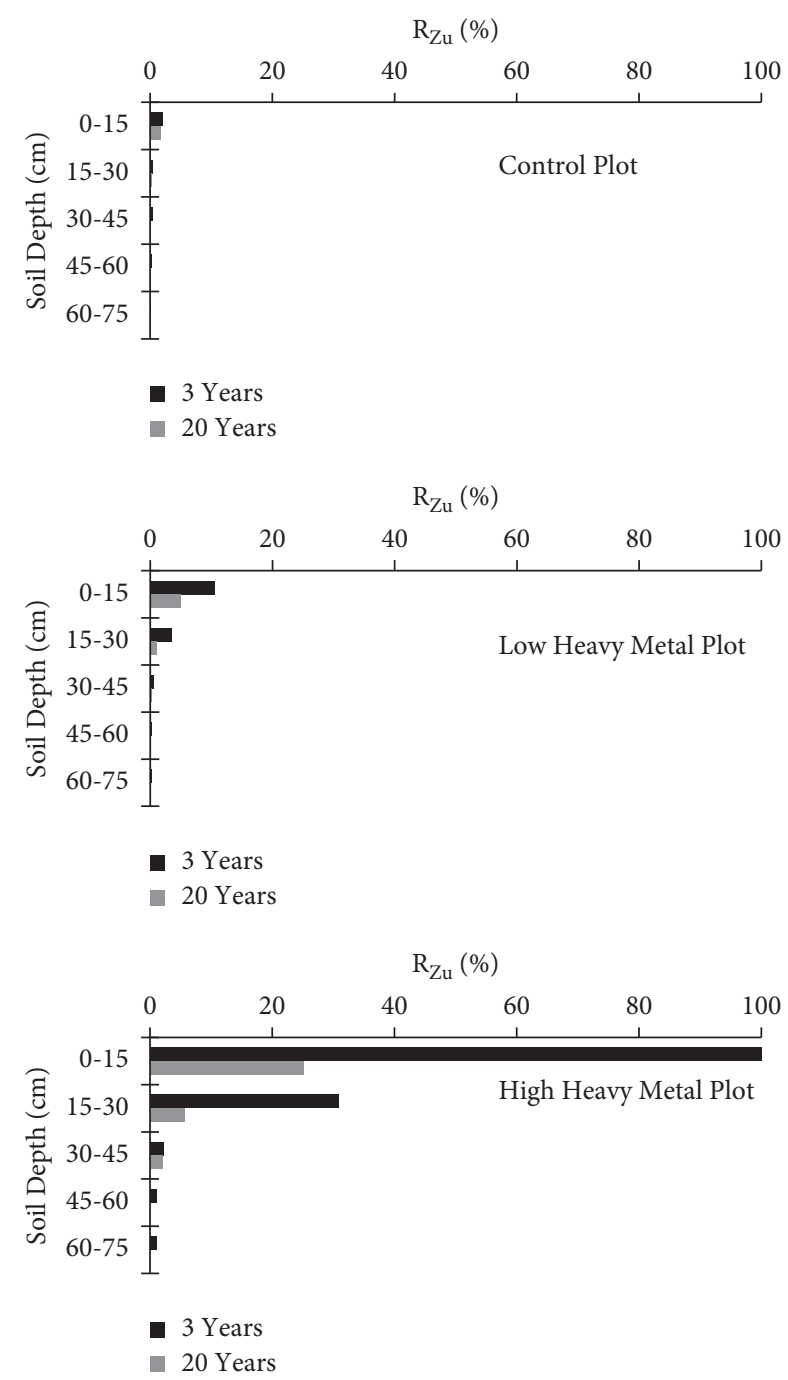

FIGURE 8: The vertical spatial distribution of soil $\mathrm{Zn} 3$ years ${ }^{1)}$ and 20 years $^{2)}$ after amendment with industrial waste $\left(\mathrm{R}_{\mathrm{Zn}}\right.$ is the ratio of the actual concentration to the highest concentration of $\mathrm{Zn}$ in the $60 \mathrm{Mg}$ waste $\mathrm{ha}^{-1}$ plot $\left(90.0 \mathrm{mg} \cdot \mathrm{kg}^{-1}\right)$; waste at $\mathrm{CP}=0, \mathrm{LMP}=15$, and $\mathrm{HMP}=60 \mathrm{Mg}$ waste $\mathrm{ha}^{-1} ;{ }^{1)}$ after [42]; ${ }^{2)}$ after Fernando and Salam (unpublished data 2018).

\section{Discussion}

The increases in the soil concentrations of $\mathrm{Cu}$ and $\mathrm{Zn}$ by waste amendment observed over 20 years as shown in Figure 5 through Figure 10 clearly indicate that parts the added $\mathrm{Cu}$ and $\mathrm{Zn}$ amended in 1998 stayed in topsoil and/or subsoil for a quite long time. The DTPA-extracted $\mathrm{Cu}$ and $\mathrm{Zn}$ in the last observations in the $60 \mathrm{Mg}$ waste ha ${ }^{-1}$ plots (HMP) 20 years after the amendment were $17-53 \%$ for $\mathrm{Cu}$ and $12-33 \%$ for $\mathrm{Zn}$ (Figures 5 and 6). Most of the amended $\mathrm{Cu}$ and $\mathrm{Zn}$ disappeared or were unextracted by DTPA 20 years after the amendment.

The high precipitation rates in the tropics in fact did not leach out all the $\mathrm{Cu}$ and $\mathrm{Zn}$ from soils. Parts of these metals were retained by soils, most probably through adsorption reactions by the soil colloid variable charges. The presence of precipitation reactions may have also possibly occurred

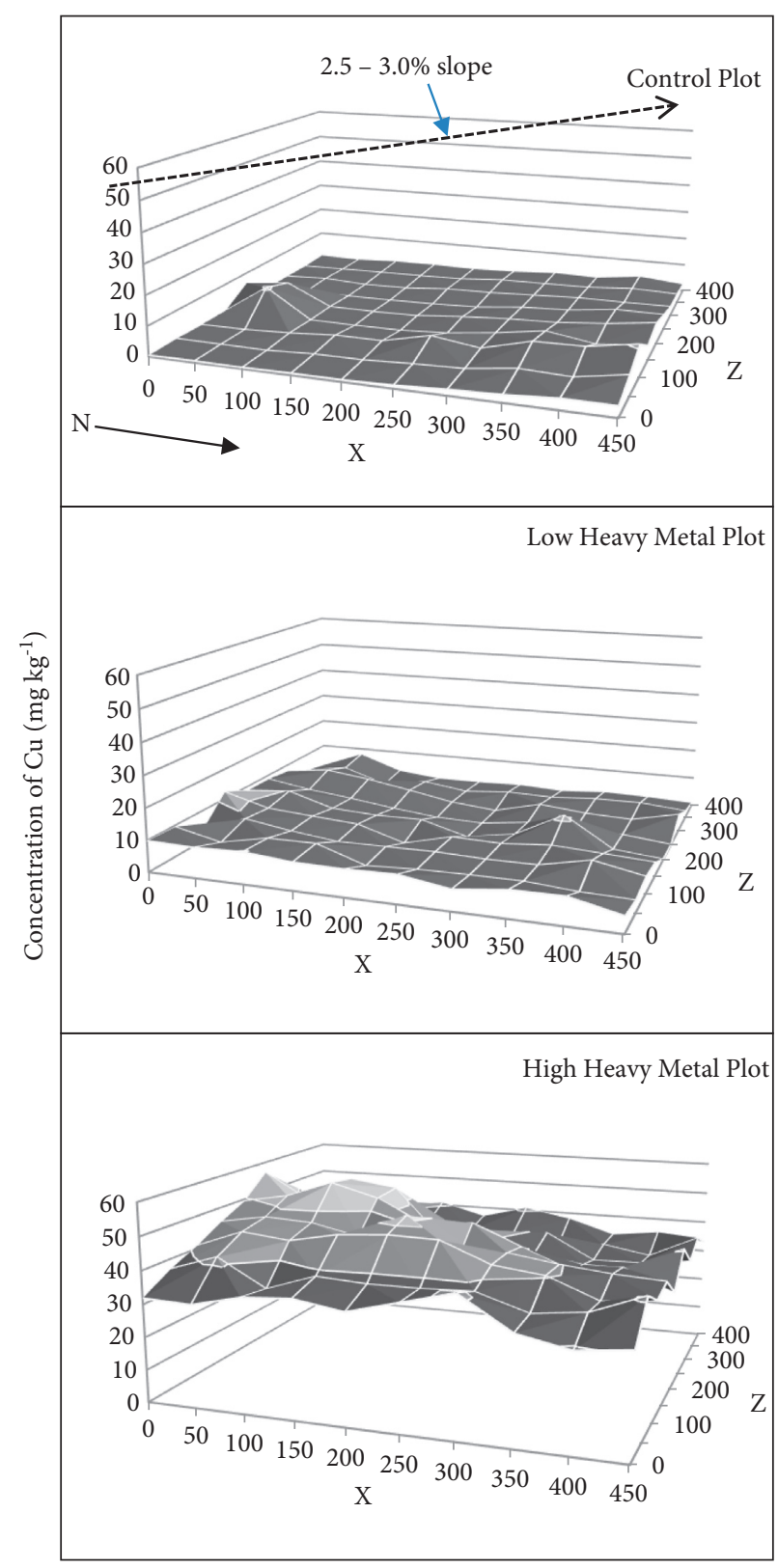

$\mathrm{X}$ or Z Distance $(\mathrm{cm})$

FIgURE 9: The horizontal spatial distribution of $\mathrm{Cu}$ in the wastetreated plots 21 years after amendment (control plot $=0$, low metal plot $=15$, and high metal plot $=60 \mathrm{Mg}$ waste $\mathrm{ha}^{-1}$; plots measured $450 \mathrm{~cm}(\mathbf{X}) \times 400 \mathrm{~cm}(\mathbf{Z})$.

because the addition of waste and/or lime and/or compost also significantly increased the soil $\mathrm{pH}$, particularly until about 10 years since their amendment in 1998 (Table 5). This observation shows that the tropical soil was effective in retaining part of heavy metals for a quite long time. The effectiveness of this soil in retaining soil $\mathrm{Cu}$ and $\mathrm{Zn}$ increased in the presence of organic compost and/or lime (Figures 5 and 6). In general, organic compost and/or lime increased the soil adsorption capacity and thereby effectively lowered the soil concentrations of $\mathrm{Cu}$ and $\mathrm{Zn}$. As reported, organic compost may have provided some organic functional groups 


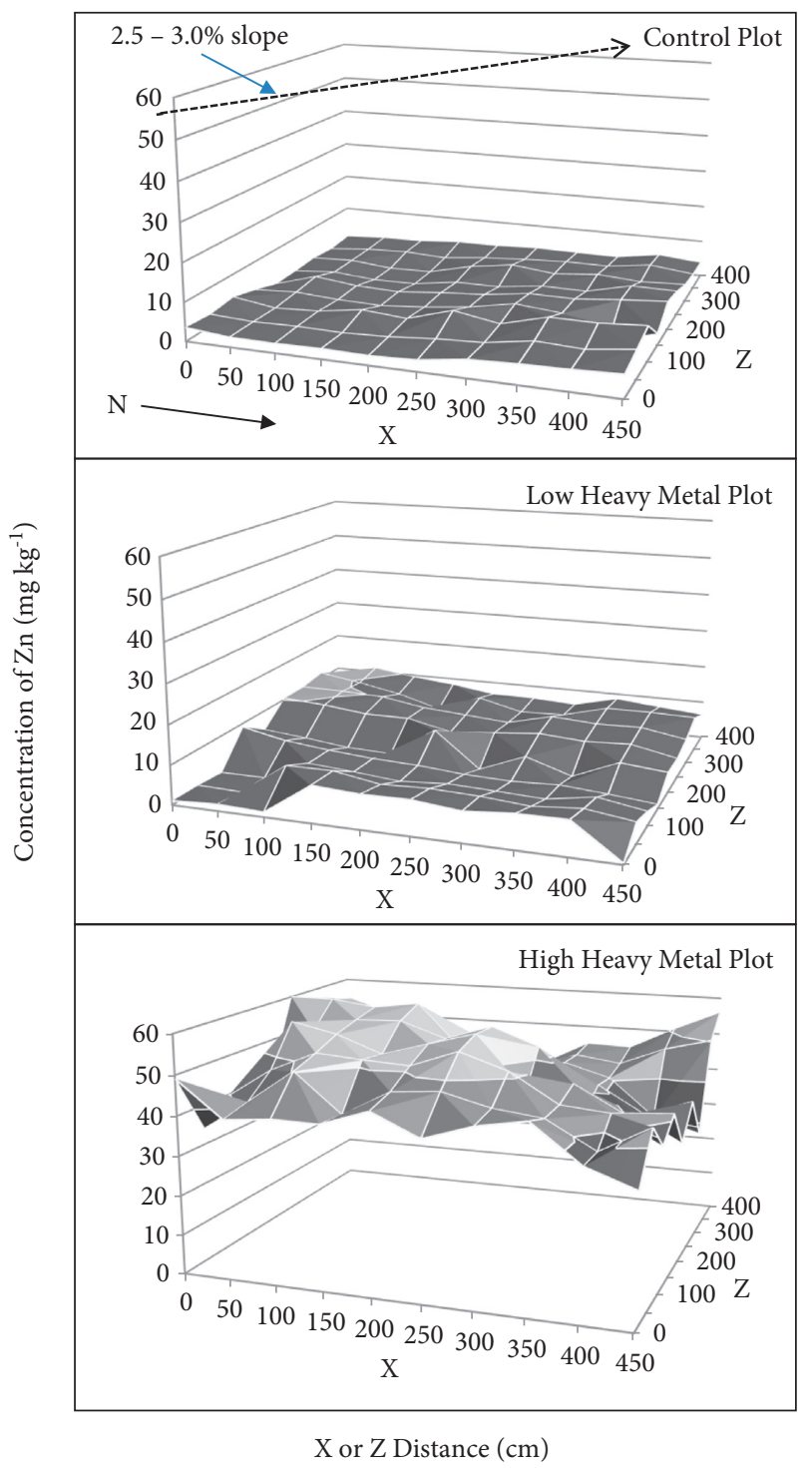

Figure 10: The horizontal spatial distribution of $\mathrm{Zn}$ in the waste-treated plots 21 years after amendment (control plot $=0$, low metal

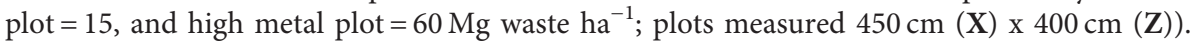

which may, when combined with the increase in soil $\mathrm{pH}$, have increased the soil negative charges able to increase the $\mathrm{Cu}$ and $\mathrm{Zn}$ immobilization by soils [20-24].

This inability of organic compost alone to lower the concentrations of $\mathrm{Cu}$ and $\mathrm{Zn}$ like right after amendment in 1998 [23] (Tables 3 and 4) was obviously caused by the probable quick decays of organic matter over time, particularly in the tropics where the relatively high moisture content may accelerate the enzymatic organic matter decomposition [53]. The decomposition process of organic matter may lower the effectiveness of organic matter in decreasing the soil concentrations of $\mathrm{Cu}$ and $\mathrm{Zn}$. Based on their researches, [43] reported that organic matter incorporation was indeed useful to retain part of heavy metals in mine soils, but they suggested that the decomposition of organic matter by soil microorganisms may cause the release of heavy metals to more readily available forms in the future. It was also reported that the oxidation of soils with dilute
$\mathrm{H}_{2} \mathrm{O}_{2}$ significantly decreased the adsorbed $\mathrm{Cu}$ and slightly decreased the adsorbed $\mathrm{Zn}$ onto organic substances [44]. Organic matter decomposition may then in general increase the $\mathrm{Cu}$ and $\mathrm{Zn}$ mobility and availability in soils. More durable organic matter like biochar may probably give a more significant effect over a longer time of process [54].

However, when combined with waste or lime, organic compost significantly decreased the soil concentrations of $\mathrm{Cu}$ and $\mathrm{Zn}$ (Tables 3 and 4, Figures 5 and 6) for some time of observation. The increase in soil $\mathrm{pH}$ due to waste or lime treatment (Table 5) may have enhanced the adsorption sites on the remaining organic matter functional groups. This process may have eventually decreased the soil concentrations of $\mathrm{Cu}$ and $\mathrm{Zn}$. The significant effect of organic compost was also observed after 3,10 , and 20 years when compost was combined with waste and lime (Tables 3 and 4, Figures 5 and 6). The presence of $\mathrm{OH}^{-}$ions at higher soil $\mathrm{pH}$ by lime may have detached bonded $\mathrm{H}$ on the organic matter functional 
TABLe 6: The changes in the concentrations of $\mathrm{Cu}$ and $\mathrm{Zn}$ in soil over 21 years from 1998 to 2019.

\begin{tabular}{|c|c|c|c|c|c|}
\hline \multirow{2}{*}{ Metal } & \multirow[b]{2}{*}{$\begin{array}{l}\text { Waste treatment in } 1998^{1)} \\
\mathrm{mg} \cdot \mathrm{ha}^{-1}\end{array}$} & \multicolumn{2}{|c|}{ Concentration in } & \multicolumn{2}{|c|}{ Changes over 21 years } \\
\hline & & $1998^{2)}$ & $\begin{array}{c}2019^{3)} \\
\mathrm{mg} \cdot \mathrm{kg}^{-1}\end{array}$ & Chan & ears \\
\hline \multirow{3}{*}{$\mathrm{Cu}$} & 0 & 0.240 & 2.43 & +2.19 & +9.12 \\
\hline & 15 & 89.0 & 4.90 & -84.1 & -94.0 \\
\hline & 60 & 94.2 & 39.6 & -54.6 & -54.6 \\
\hline \multirow{3}{*}{$Z n$} & 0 & 0.98 & 3.51 & +2.53 & +258 \\
\hline & 15 & 61.2 & 6.10 & -55.1 & -90.0 \\
\hline & 60 & 53.5 & 45.2 & -8.35 & -15.0 \\
\hline
\end{tabular}

${ }^{1)}$ Waste was amended one time; ${ }^{2)}$ after Suryanti and Salam (unpublished data 1998); ${ }^{3)}$ average of 3 blocks.

groups causing the increase in the adsorption sites that were important for heavy metal adsorption [20-24].

At an earlier time, i.e., at \pm 1.5 and \pm 3 years, the role of lime and/or cassava-leaf compost was clearly observed (Figures 5 and 6). The soil concentrations of $\mathrm{Cu}$ (Figure 5) and $\mathrm{Zn}$ (Figure 6) were depressed by compost and/or lime treatment. The organic matter enhanced the soil capacity to retain heavy metal cations as negatively charged functional groups and the raised soil $\mathrm{pH}$ by lime enlarged the quantity of the negatively charged organic matters and soil clays $[12,55]$ that were able to retain more $\mathrm{Cu}$ and $\mathrm{Zn}$ cations. However, the role of these factors faded with the time of sampling more than 3 years. After 3 years, the presence of compost solubilized $\mathrm{Cu}$ and $\mathrm{Zn}$. However, the interactions of lime and compost in the presence of waste were in general observed to lower the soil concentrations of $\mathrm{Cu}$ and $\mathrm{Zn}$ (Figures 5 and 6). The chemical reactions which include adsorption and precipitation of $\mathrm{Cu}$ and $\mathrm{Zn}$ might have also been involved in decreasing the soil concentration of $\mathrm{Cu}$ and $\mathrm{Zn}$ over 20 years. Since the initial soil $\mathrm{pH}$ was low $(\mathrm{pH}=5.11)$, the adsorption reaction probably dominated $[12,23]$. Even though the soil CEC was relatively low, to some extent, the $\mathrm{Cu}$ and $\mathrm{Zn}$ adsorption may have caused a decrease in the concentrations of $\mathrm{Cu}$ and $\mathrm{Zn}$ in soil [12].

As clearly shown in Figure $5, \mathrm{R}_{\mathrm{Cu}}$ in the $60 \mathrm{Mg}$ waste $\mathrm{ha}^{-1}$ plot (HMP) decreases with the time of sampling. For example, $R_{C u}$ at $\pm 1.5, \pm 3, \pm 10$, and 20 years is $100,77,19$, and $53 \%$, respectively (Figure 5). A similar pattern was observed for $\mathrm{Zn}$ (Figure 6). $\mathrm{R}_{\mathrm{Zn}}$ in general also decreases with the time of sampling. These values indicate that the soil concentrations of $\mathrm{Cu}$ and $\mathrm{Zn}$ decreased with time. Some of the $\mathrm{Cu}$ and $\mathrm{Zn}$ were removed from their labile pools and were shifted to other forms over time depending on compost and/or lime treatment. Several possibilities may explain the phenomenon of $\mathrm{Cu}$ and $\mathrm{Zn}$ decreases over time in Figures 5 and 6 . The heavy metals released into the soil solution may have encountered various fates as suggested by $[31,55]$ shown in Figure 11, which include absorption by plants $[32,34]$ or leached through the soil bodies $[29,40]$ or transported away by mass flow, diffusion, water runoff and erosion, and plowing/tillage [35, 37, 39, 41, 56, 57].

One of the important physical processes that may have changed the concentrations of $\mathrm{Cu}$ and $\mathrm{Zn}$ was the heavy metal movement through mass flow and diffusion. Mass flow follows the direction of water movement which includes heavy metal leaching by percolating water. The high rain intensity during the rainy season in South Lampung might have fastened the movement of $\mathrm{Cu}$ and $\mathrm{Zn}$ from topsoils to subsoils through mass flow and leaching. As previously mentioned, the total rainfall in the area was $1.628 \mathrm{~mm}$ in 2015 with 143 total rainy days [51]. The higher concentrations of $\mathrm{Cu}$ and $\mathrm{Zn}$ in subsoils (soil depths $>0-15 \mathrm{~cm}$ ) in plots amended with industrial waste (LMP and HMP) than those in CP (Figures 7 and 8) suggest that $\mathrm{Cu}$ and $\mathrm{Zn}$ may have one way or another moved from topsoils to subsoils. The current data (Figures 7 and 8) also show that the concentrations of $\mathrm{Cu}$ and $\mathrm{Zn}$ were the highest in the 0-15 cm layers of LMP and HMP where waste was amended in 1998 even though in HMP significant amounts of $\mathrm{Cu}$ and $\mathrm{Zn}$ were also observed in 30-60 cm layers. The movement is, however, minuscule, particularly to soil depth $>30 \mathrm{~cm}$. Figures 7 and 8 show that in general the concentrations of $\mathrm{Cu}$ and $\mathrm{Zn}$ at 20 years were lower than those at 3 years, with the exception of $\mathrm{Cu}$ at waste level $\leq 15 \mathrm{Mg} \cdot \mathrm{ha}^{-1}$. The paper [42] also previously showed that after \pm 3 years, $\mathrm{Cu}$ and $\mathrm{Zn}$ were leached in smaller amounts, and, overall, the $\mathrm{Cu}$ and $\mathrm{Zn}$ were not significantly moved to subsoils. Most of the heavy metals may have been adsorbed onto the higher energy sites and probably also absorbed by plant roots.

The physical processes like plowing and harrowing were probably the most important in moving the masses of $\mathrm{Cu}$ and $\mathrm{Zn}$. These physical activities may have shifted the heavy metals in soils out of the plot boundaries and to other adjacent and nearby plots. The decreases in $\mathrm{Cu}$ and $\mathrm{Zn}$ concentrations in LMP and HMP and the increases in their concentrations in $\mathrm{CP}$ over 20 years after waste amendment (Table 6) support this suggestion. The higher concentrations of $\mathrm{Cu}$ at 20 than those at 3 years in $0-15 \mathrm{~cm}$ layers of $\mathrm{CP}$ and LMP (Figure 7) may also support these suggestions. Parts of $\mathrm{Cu}$ and $\mathrm{Zn}$ from the adjacent LMP and HMP may have been transported to CP. Plowing may have also exchanged the masses of topsoils and subsoils and surely decreased the new topsoil concentrations of $\mathrm{Cu}$ and $\mathrm{Zn}$. These phenomena were in accordance with those reported by [41]. The significant decreases in the topsoil $\mathrm{Cu}$ and $\mathrm{Zn}$ concentrations (Table 6) were probably also caused by this physical process. The paper [42] also shows that the concentrations of $\mathrm{Cu}$ and $\mathrm{Zn}$ in the underlying soil layers in plots treated with the industrial waste were significantly higher than the same layers in the control plots. The underlying layers of heavy metals 


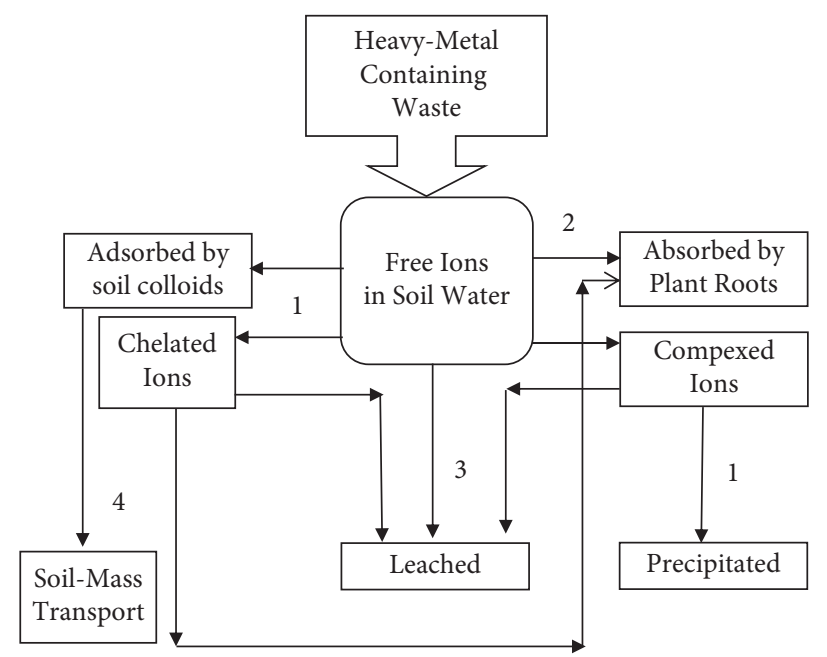

Figure 11: The possibilities of the waste-origin $\mathrm{Cu}$ and $\mathrm{Zn}$ removals from soil labile fractions after waste amendment (1: adsorption or precipitation, 2: absorption by plant roots, 3: leaching, 4: soil mass transport) [50, 55].

were probably contributed by topsoil $\mathrm{Cu}$ and $\mathrm{Zn}$ in which the heavy metals were initially given in topsoils $(0-15 \mathrm{~cm})$ in 1998. Therefore, the $\mathrm{Cu}$ and $\mathrm{Zn}$ may have moved by soil tillage (particularly that in $0-30 \mathrm{~cm}$ ) and also by water leaching. However, most $\mathrm{Cu}$ and $\mathrm{Zn}$ residues were observed to remain in topsoils.

The horizontal movement of $\mathrm{Cu}$ and $\mathrm{Zn}$ like this may have also occurred by water runoff and soil erosion suggested by [36] because the experimental land in Sidosari tilted about 2.5-3.0\% to the northwest direction (Figure 2). Figures 9 and 10 show that the concentrations of $\mathrm{Cu}$ and $\mathrm{Zn}$ were generally higher in the northwest corners of the plots than those in other parts of the plots, particularly in plots with $60 \mathrm{Mg}$ waste ha ${ }^{-1}$. The plowing and harrowing may ease the water runoff and soil mass erosion. Therefore, soil tillage may cause not only vertical but also horizontal movement of soil mass containing heavy metals.

In addition to the physical and chemical processes, the extraction of $\mathrm{Cu}$ and $\mathrm{Zn}$ by plants grown and harvested from the experimental plots might have also caused significant decreases in the soil concentrations of $\mathrm{Cu}$ and $\mathrm{Zn}$ [13]. The experimental soils in Sidosari had been planted with various plant crops including cassava (Manihot utilissima), upland rice (Oryza sativa), spinach, and corn (Zea mays) since the industrial waste was amended in 1998. As cited by [13, 29], crop removal and leaching may have been the main causes of heavy metal losses from the soil system. The results of all these factors may have eventually decreased the concentrations of $\mathrm{Cu}$ and $\mathrm{Zn}$ in topsoils. However, this suggestion needs further research.

Our current glasshouse investigation using the soil samples from CP, LMP, and HMP showed that water spinach (Ipomoea aquatica) was able to decrease the soil $\mathrm{Zn}$ by as much as $38.5 \%$ in CP, $21.6 \%$ in LMP, and $16.0 \%$ in HMP. Other investigations also revealed that the uptake of $\mathrm{Cu}$ increased with corn plant biomass with a high correlation coefficient $\left(R^{2}=0.95^{*}\right)$. The decrease in soil $\mathrm{Cu}$ and $\mathrm{Zn}$ was assumed to be caused by plant absorption and immobilization by soils because plants were watered capillary. Therefore, no heavy metal leaching occurred.

The above experimental data clearly showed that significant parts of amended $\mathrm{Cu}$ and $\mathrm{Zn}$ were immobilized by soil colloids for a quite a long time. Some other parts were translocated through several chemical, physical, and biological mechanisms like soil chemical immobilization, physical movement such as soil erosion, plowing, and leaching, and crop removals.

\section{Conclusion}

Significant increases in the soil concentrations of $\mathrm{Cu}$ and $\mathrm{Zn}$ caused by waste were observed over 20 years after treatment. The increase in $\mathrm{pH}$ by lime was observed over 10 years but its effect on the soil concentrations of $\mathrm{Cu}$ and $\mathrm{Zn}$ was observed only at 1.5 years, particularly in topsoils. However, the effect of lime was observed over 20 years when waste and/or compost were also given. Similarly, the effect of compost was absent over 20 years but was significant when waste and/or lime were also given. The relative concentration of $\mathrm{Cu}$ and $\mathrm{Zn}$ in the $60 \mathrm{Mg}$ waste ha ${ }^{-1}$ plots decreased over 20 years to $17-53 \%$ for $\mathrm{Cu}$ and to $12-33 \%$ for $\mathrm{Zn}$; their concentrations were, in general, lower with lime and/or compost. Copper and $\mathrm{Zn}$ were not evenly distributed over each plot. The relative concentrations of $\mathrm{Cu}$ and $\mathrm{Zn}$ significantly decreased over 21 years in plots with 15 or $60 \mathrm{Mg} \cdot \mathrm{ha}^{-1}$ and increased in the control plots. The concentrations of $\mathrm{Cu}$ and $\mathrm{Zn}$ were the highest in the 0-15 layers of low metal plots and high metal plots where waste was amended in 1998 and then in 15-30 layers. Some significant amounts of $\mathrm{Cu}$ and $\mathrm{Zn}$ were observed in $30-60 \mathrm{~cm}$ layers, particularly in high metal plots, indicating $\mathrm{Cu}$ and $\mathrm{Zn}$ vertical movement. Heavy metals moved in soil mostly through soil tillage and erosion and partially through leaching. 


\section{Data Availability}

The raw and analyzed data used to support this study are available from the corresponding author upon request.

\section{Conflicts of Interest}

The authors declare that there are no conflicts of interest.

\section{Acknowledgments}

The funding by the Directorate General of Higher Education the Ministry of National Education, the Republic of Indonesia, particularly in the initial setting of the experimental plots through Competitive Research Grant in 1995-1999 is appreciated. Gratitude is extended also to Suwarto, the former soil and plant analyst in the Laboratory of Soil Science of the University of Lampung, for the help in conducting the laboratory work, and also to Sri Djuniwati (deceased), from IPB University Indonesia, for her participation at the beginning of this research project.

\section{References}

[1] M. Biasioli, H. Grčman, T. Kralj, F. Madrid, E. Díaz-Barrientos, and F. Ajmone-Marsan, "Potentially toxic elements contamination in urban soils," Journal of Environmental Quality, vol. 36, no. 1, pp. 70-79, 2007.

[2] G. U. Chibuike and S. C. Obiora, "Heavy metal polluted soils: effect on plants and bioremediation methods," Applied and Environmental Soil Science, vol. 2014, Article ID 752708, 12 pages, 2014.

[3] M. Gill and M. Gill, "Heavy metal stress in plants: a review," International Journal of Advanced Research, vol. 2, no. 6, pp. 1043-1055, 2014.

[4] A. Aksu, "Sources of metal pollution in the urban atmosphere (A case study: tuzla, Istanbul)," Journal of Environmental Health Science and Engineering, vol. 13, no. 1, p. 79, 2015.

[5] I. P. Adejoh, "Assessment of heavy metal contamination of soil and cassava plants within the vicinity of a cement factory in north central Nigeria," Advances in Applied Science Research, vol. 7, no. 3, pp. 20-27, 2016.

[6] N. Arif, V. Yadav, S. Singh, S. Singh, and P. Ahmad, "Influence of high and low levels of plant-beneficial heavy metal ions on plant growth and development," Frontiers of Environmental Science \& Engineering, vol. 4, no. 69, pp. 1-10, 2016.

[7] A. Asati, M. Pichhode, and K. Nikhil, "Effect of heavy metals on plants: an overview," International Journal of Application or Innovation in Engineering \& Management, vol. 5, no. 3, pp. 56-66, 2016.

[8] E. Popova, "Accumulation of heavy metals in the "soil-plant" system," AIP Conference Series, vol. 1772, Article ID 050006, 2016.

[9] T. Gaza and J. Kugara, "Study of heavy metal air pollution, using a moss (Grimmia dissimulate) biomonitoring technique," Universal Journal of Chemistry, vol. 6, no. 1, pp. 1-13, 2018.

[10] N. Timothy and E. T. Williams, "Environmental pollution by heavy metal: an overview," International Journal of Environmental Chemistry, vol. 3, no. 2, pp. 72-82, 2019.

[11] A. Aprile and L. De Bellis, "Editorial for Special Issue "Heavy metals accumulation, toxicity, and detoxification in plants","
International Journal of Molecular Sciences, vol. 21, no. 4103, 2020.

[12] A. K. Salam and P. A. Helmke, "The $\mathrm{pH}$ dependence of free ionic activities and total dissolved concentrations of copper and cadmium in soil solution," Geoderma, vol. 83, no. 3-4, pp. 281-291, 1998.

[13] R. A. Wuana and F. E. Okieimen, "Heavy metals in contaminated soils: a review of sources, chemistry, risks and best available strategies for remediation," International Scholarly Research Notices, vol. 2011, Article ID 402647, 20 pages, 2011.

[14] P. M. Suguru, "Simulated in-situ immobilization of heavy metals in selected soils of Karnataka," Fungal Genomics \& Biology, vol. 5, no. 1, pp. 1-6, 2015.

[15] N. Abdu and I. Mohammed, "Adsorption-solubility equilibria and speciation of $\mathrm{Pb}, \mathrm{Cd}$, and $\mathrm{Zn}$ in a savanna soil," Spanish Journal of Soil Science, vol. 6, no. 3, pp. 244-260, 2016.

[16] R. Xiao, Z. Huang, X. Li, W. Chen, Y. Deng, and C. Han, "Lime and phosphate amendment can significantly reduce uptake of $\mathrm{Cd}$ and $\mathrm{Pb}$ by field-grown rice," Sustainability, vol. 9, no. 430, pp. 2-10, 2017.

[17] Y. Luo, "Study on the repair of heavy metal contaminated soil," IOP Conference Series: Earth and Environmental Science, vol. 300, Article ID 032076, 2019.

[18] A. Selvi, A. Rajasekar, and J. Theerthagiri, "Integrated remediation processes toward heavy metal removal/recovery from various environments-a review," Frontiers in Environmental Science, vol. 7, 2019.

[19] J. Saloua, T. Mohamed, M. Ahmed, and M. Khadija, "Industrial rejection: removal of heavy metals based on chemical precipitation and research for recoverable material in byproducts," International Journal of Engineering Technologies and Management Research, vol. 7, no. 2, pp. 39-52, 2020.

[20] K. Quenea, I. Lamy, P. Winterton, A. Bermond, and C. Dumat, "Interactions between metals and soil organic matter in various particle size fractions of soil contaminated with waste water," Geoderma, vol. 1, no. 3-4, pp. 217-223, 2009.

[21] H. M. Nasser, M. Z. Rahman, S. Sultana, M. A. Quddus, and M. A. Haqque, "Remediation of heavy metal polluted soil through organic amendments," Bangladesh Journal of Agricultural Research, vol. 42, no. 4, pp. 589-598, 2017.

[22] G. He, Z. Zhang, X. Wu, M. Cui, J. Zhang, and X. Huang, "Adsorption of heavy metals on soil collected from Lixisol of typical karst areas in the presence of $\mathrm{CaCO}_{3}$ and soil clay and their competition behavior," Sustainability, vol. 12, no. 7315, 2020.

[23] A. K. Salam, "A four year study on the effects of manipulated soil $\mathrm{pH}$ and organic matter contents on availabilities of industrial-waste-origin heavy-metals in tropical soils," Journal of Tropical Soils, vol. 11, pp. 31-46, 2000.

[24] V. Angelova, R. Ivanova, G. Pevicharova, and K. Ivanov, "Effect of organic amendments on heavy metals uptake by potato plants," in Proceedings of the 19th World Congress of Soil Science, 2010, pp. 84-87, Brisbane, Australia, August 2010.

[25] W. Buss, C. Kammann, and H. Koyro, "Biochar reduces copper toxicity in Chenopodium quinoa Willd. in a sandy soil," Journal of Environmental Quality, vol. 40, 2011.

[26] A. Hayyat, M. Javed, I. Rasheed et al., "Role of biochar in remediating heavy metals in soil," Phytoremediation, vol. 14, pp. 421-437, 2016.

[27] M. Guo, W. Song, and J. Tian, "Biochar-facilitated soil remediation: mechanisms and efficacy variations," Frontiers in Environmental Science, vol. 8, 2020. 
[28] B. K. Richards, T. S. Steenhuis, J. H. Peverly, and M. B. Mcbride, "Metal mobility at an old, heavily loaded sludge application site," Environmental Pollution, vol. 99, no. 3, pp. 365-377, 1998.

[29] J. Duus, S. Lekfeldt, P. E. Holm, C. Kjærgaard, and J. Magid, "Heavy metal leaching as affected by long-time organic waste fertilizer application," Journal of Environmental Quality, vol. 46, pp. 871-878, 2017.

[30] B. F. Sukkariyah, G. Evanylo, L. Zelazny, and R. L. Chaney, "Cadmium, copper, nickel, and zinc availability in a biosolidsamended piedmont soil years after application," Journal of Environmental Quality, vol. 34, no. 6, pp. 2255-2262, 2005.

[31] K. Pachana, A. Wattanakornsiri, and J. Nanuam, "Heavy metal transport and fate in the environmental compartments," New Scientist, vol. 7, no. 1, pp. 1-11, 2010.

[32] C. O. Ogunkunle, P. O. Fatoba, A. O. Oyedeji, and O. O. Awotoye, "Assessing the heavy metal transfer and translocation by Sida acuta and Pennisetum purpureum for phytoremediation purposes," Albanian Journal of Agricultural Sciences, vol. 13, no. 1, pp. 71-80, 2014.

[33] C. Payus, A. Farhana, A. Talip, and T. Hsiang, "Heavy metals accumulation in paddy cultivation area of Kompipinan, Papar District, Sabah," Journal of Sustainability Science and Management, vol. 10, no. 1, pp. 76-86, 2015.

[34] N. K. Glavač, S. Djogo, S. Ražić, S. Kreft, and M. Veber, "Accumulation of heavy metals from soil in medicinal plants," Arhiv Za Higijenu Rada I Toksikologiju, vol. 68, pp. 236-244, 2017.

[35] L. Yingming and R. B. Corey, "Redistribution of sludge-borne cadmium, copper, and zinc in a cultivated plot," Journal of Environmental Quality, vol. 22, no. 2, pp. 1-8, 1993.

[36] Z. L. He, M. K. Zhang, P. J. Stoffella, X. E. Yang, and D. J. Banks, "Phosphorus concentrations and loads in runoff water under crop production," Soil Science Society of America Journal, vol. 70, no. 5, pp. 1807-1816, 2006.

[37] T. A. Elbana and H. M. Selim, "Cadmium transport in alkaline and acidic soils: miscible displacement experiments," Soil Science Society of America Journal, vol. 74, no. 6, 2010.

[38] R. Ladachart, C. Sutthirat, K. Hisada, and P. Charusiri, "Soil erosion and heavy metal contamination in the middle part of the songkhla lake coastal area, southern Thailand," Coastal Environments: Focus on Asian Regions, vol. 8, pp. 106-129, 2014.

[39] I. A. Nweke, S. I. Ijearu, and N. Dambaba, "Interactive effect of tillage and wood ash on heavy metal content of soil, castor shoot and seed," International Journal of Advanced Engineering Research and Science, vol. 4, no. 11, pp. 14-27, 2017.

[40] C.-Y. Chu and T.-H. Ko, "Evaluation of acid leaching on the removal of heavy metals and soil fertility in contaminated soil," Journal of Chemistry, vol. 2018, Article ID 5036581, 8 pages, 2018.

[41] F. J. K. Mallmann, D. d. S. Rheinheimer, C. A. Ceretta et al., "Soil tillage to reduce surface metal contamination - model development and simulations of zinc and copper concentration profiles in a pig slurry-amended soil," Agriculture, Ecosystems \& Environment, vol. 196, pp. 59-68, 2014.

[42] A. K. Salam, S. Bakrie, and F. Prihatin, "Depth-wise distribution of extracted $\mathrm{Cu}$ and $\mathrm{Zn}$ in cultivated field-plots after treatment with a $\mathrm{Cu}$ - and $\mathrm{Zn}$-containing waste, lime, and cassava-leaf compost," Journal of Tropical Soils, vol. 11, no. 1, pp. 9-14, 2005.

[43] E. S. Bendfeldt, J. A. Burger, and W. L. Daniels, "Quality of amended mine soils after sixteen years," Soil Science Society of America Journal, vol. 65, no. 6, pp. 1736-1744, 2001.
[44] M. H. Stietiya and J. J. Wang, "Effect of organic matter oxidation on the fractionation of copper, zinc, lead, and arsenic in sewage sludge and amended soils," Journal of Environmental Quality, vol. 40, no. 4, pp. 1162-1171, 2011.

[45] S. Cheng, "Effects of heavy metals on plants and resistance mechanisms," Environmental Science and Pollution Research, vol. 10, no. 4, pp. 256-264, 2003.

[46] Q. Jamal, K. Khan, S. Munir, and M. Anees, "Heavy metals accumulation and their toxic effects: review," Journal of BioScience, vol. 1, no. 1, pp. 27-36, 2013.

[47] V. Srivastava, A. Sarkar, S. Singh, P. Singh, and A. S. F. De Araujo, "Agroecological responses of heavy metal pollution with special emphasis on soil health and plant performances," Frontiers in Environmental Science, vol. 5, no. 64, pp. 1-19, 2017.

[48] F. Ayari, H. Hamdi, N. Jedidi, N. Gharbi, and R. Kossai, "Heavy metal distribution in soil and plant in municipal solid waste compost amended plots," International journal of Environmental Science and Technology, vol. 7, no. 3, pp. 465-472, 2010.

[49] E. Smolders, K. Oorts, E. Lombi et al., "The availability of copper in soils historically amended with sewage sludge, manure, and compost," Journal of Environmental Quality, vol. 41, no. 2, pp. 506-514, 2012.

[50] A. K. Salam and K. Ginanjar, "Tropical soil labile fractions of copper in the experimental plots \pm Ten years after application of copper-containing-waste," Journal of Tropical Soils, vol. 23, no. 1, pp. 11-18, 2018.

[51] Statistical Beurau of South Lampung, Rata-Rata Jumlah Hari Hujan Dan Curah Hujan Setiap Bulan Di Kabupaten Lampung Selatan, Statistical Beurau of South Lampung, Lampung, Indonesia, 2015.

[52] W. L. Lindsay and W. A. Norvell, "Development of a DTPA soil test for zinc, iron, manganese, and copper," Soil Science Society of America Journal, vol. 42, no. 3, pp. 421-428, 1978.

[53] A. K. Salam, Enzymes in Tropical Soils, Global Madani Press, Bandar Lampung, Indonesia, 1st edition, 2014.

[54] Y. Wang, K. Gu, H. Wang, and B. Shi, "Remediation of heavymetal-contaminated soils by biochar: a review," Environmental Geotechnics, vol. 252, pp. 1-14, 2019.

[55] A. K. Salam, Management of Heavy Metals in Tropical Soil Environment, Bandar Lampung: Global Madani Press, Bandar Lampung, Indonesia, 1st edition, 2017.

[56] L. Fodor and L. Szabó, "Study of heavy metal leaching in the soil," in Proceedings of the 13th International Soil Conservation. Organization Conference, vol. 216, pp. 1-4, Brisbane, UK, July 2004.

[57] H. Fang, L. Huang, J. Wang, G. He, and D. Reible, "Environmental assessment of heavy metal transport and transformation in the Hangzhou Bay, China," Journal of Hazardous Materials, vol. 302, pp. 447-457, 2016. 